An Naba: Jumal Pemikiran Dan Penefitian Pendidikan Islam

Volume 3, Nomor 1, Tahun 2020 p-ISSN 2087-4642 e-ISSN 2721-1843

https://ejurnal.darulfattah.ac.id/index.php/Annaba

\title{
Pola Dan Keragaman Pendidikan Islam \\ (Kajian Tentang Pesantren dan Ruang Lingkupnya)
}

\author{
M. Wisnu Khumaidi \\ STIT Darul Fattah Bandar Lampung \\ maswisnukhhumaidi@gmail.com
}

\begin{abstract}
There is an opinion that the pesantren is rooted in Islam's own tradition of Tarikat. Pesantren has a close relationship with the special education place for the Sufi people. This opinion is based on the fact that the early first century history of Islam's entry into Indonesia is much more familiar in the form of tarikat activities. This is characterized by the formation of organization groups that carry out the practices of zikr and wirid. The Chief of the Tarikat called Kyai, which required his followers to perform the Suluk. Suluk is living with fellow Tarikat members in a mosque for 40 days to perform worship under the guidance of the Order of the order. For the purposes of these Suluk, the Kyai provides special rooms for lodging and cooking places located on the left-hand of the mosque. Besides teaching the practices of the order, the followers also taught the books of religion in various branches of Islamic sciences. The activities performed by the followers of this order are then called the study. In the next development, this institution grew and developed into a pesantren. Thus, the pesantren at that time served as a center of Islamic teaching and education and the center of the spread of Islamic religion.
\end{abstract}

Keywords : pesantren, islamic education

\begin{abstract}
ABSTRAK
Ada pendapat yang menyatakan bahwa pesantren berakar dari tradisi Islam sendiri yaitu tradisi tarikat. Pesantren mempunyai kaitan yang erat dengan tempat pendidikan yang khas bagi kaum sufi. Pendapat ini berdasarkan fakta bahwa waktu awal abad pertama sejarah masuknya Islam ke Indonesia lebih banyak di kenal dalam bentuk kegiatan tarikat. Hal ini ditandai dengan terbentuknya kelompok-kelompok organisasi tarikat yang melaksanakan amalan-amalan zikir dan wirid. Pimpinan tarikat yang disebut kyai, yang mewajibkan pengikutnya untuk melaksanakan suluk. Suluk ialah tinggal bersama sesama anggota tarikat di sebuah masjid selama 40 hari untuk melakukan ibadah-ibadah dibawah bimbingan seoarang pempinan tarekat. Untuk keperluan suluk ini, para kyai menyediakan ruangan khusus untuk penginapan dan tempat masak yang terletak di kanan kiri masjid. Disamping mengajarkan amalan-amalan tarekat, para pengikut itu juga diajarkan kitab-kitab agama dalam berbagai cabang ilmu pengetahuan ilmu agama Islam. Aktivitas yang dilakukan oleh para pengikut tarekat ini kemudian dinamakan pengajian. Dalam perkembangan selanjutnya lembaga pengajian ini tumbuh dan berkembang menjadi lembaga pesantren. Dengan demikian, pesantren pada masa itu berperan sebagai pusat pengajaran dan pendidikan Islam dan sekaligus pusat penyebaran agama Islam.
\end{abstract}

Kata Kunci : Pesantren, Pendidikan Islam 


\section{PENDAHULUAN}

Sebelum menuju ke pembahasan inti yaitu tentang pesantren, ada baiknya peneliti menyampaikan tentang metode penelitian yang dilakukan adalah kajian pustaka deskriptif kualitatif. Diharapkan dengan adanya tulisan ini, dapat menjadi tambahan khazanah keilmuan dan informasi, khusunya dalam hal kepesantrenan khususnya di bumi nusantara ini.

Perkataan pesantren berasal dari kata santri, dengan awal pe akhiran an, berarti tempat tinggal para santri. Dalam Kamus Bahasa Indonesia, pesantren diartikan sebagai asrama tempat santri atau tempat murid-murid belajar mengaji. Soegarda Poerbakawatja juga menjelaskan bahwa pesantren berasal dari kata santri, yaitu seorang yang belajar agama Islam, dengan demikian pesantren mempunyai arti tempat orang-orang berkumpul untuk belajar agama Islam.

Menurut Rahim (2001 : 28), pesantren merupakan sebuah lembaga pendidikan tertua yang melekat dalam perjalanan kehidupan Indonesia sejak ratusan tahun yang silam. Ia adalah lembaga pendidikan yang dapat dikategorikan sebagai lembaga unik dan punya karakteristik tersendiri yang khas, sehingga saat ini menunjukkan kapabilitasnya yang cemerlang melewati berbagai episode zaman dengan pluralitas polemik yang dihadapinya. Bahkan dalam perjalanan sejarahnya, pesantren telah banyak memberikan andil dan kontribusi yang sangat besar dalam ikut serta mencerdaskan kehidupan bangsa dan memberikan pencerahan terhadap masyarakat serta dapat menghasilkan komunitas intelektual yang setaraf dengan sekolah gubernemen.

Oleh karena itu tak mengherankan bila pakar pendidikan sekalas Ki Hajar Dewantoro dan Dr. Soetomo pernah mencita-citakan model system pendidikan pesantren sebagai model pendidikan Nasional. Bagi mereka model pendidikan pesantren merupakan kreasi cerdas budaya Indonesia yang berkarakter dan patut untuk terus dipertahan kembangkan.

M. Arifin merumuskan difinisi pesantren sebagai berikut, "Pondok Pesantren adalah suatu lembaga pendidikan agama Islam yang tumbuh serta diakui oleh masyarakat sekitar, dengan sistem asrama atau kampus, dimana para santri menerima pendidikan agama melalui sistem pengajian atau madrasah yang sepenuhnya dibawah kedaulatan dari leadership seorang atau beberapa orang kyai dengan ciri-ciri khas yang bersifat kharismatik serta independen dalam segala hal”.

Dari sinilah peneliti tergelitik untuk melakukan penelitian terhadap pendidikan pondok pesantren tradisional dalam perspektif pendidikan Islam Indonesia dalam rangka mencari sesuatu yang mungkin belum tersentuh dan tidak terfikirkan oleh sistem pendidikan Islam di Indonesia. 
Penelitian ini bergulat dengan refleksi pendidikan Islam di Pondok Pesantren tradisional dalam bentuk kajian pustaka deskriptif kualitatif. Salah satu tujuannya adalah untuk menyadarkan masyarakat akan pentingnya pendidikan Islam serta menciptakan pemahaman pendidikan Islam yang lebih progresif konstekstual sehingga mampu menjawab tantangan zaman.

Berdasarkan laporan pemerintah Hindia Belanda diketahui bahwa pada tahun 1831 di Indonesia ada sejumlah 1.853 buah lembaga pendidikan Islam tradisional dengan jumlah murid 16.556 orang.Sedangkan berdasarkan hasil pendataan yang dilaksanakan oleh Departemen Agama tahun 1984-1985 diperoleh keterangan bahwa jumlah pesantren di Indonesia abad ke-16 sebanyak 613 buah pesantren tertua didirikan pada tahun 1062 di Pamekasan Madura, dengan nama pesantren Jan Tampes II. Akan tetapi hal ini diragukan, karena tentunya ada pesantren Jan Tampes I yang lebih tua usianya.

Pesantren berhasil menjadikan dirinya sebagai pusat gerakan pengembangan Islam, hal ini seperti yang diakui oleh Dr. Soebardi dan Prof. Johns, yang dikutip oleh Zamahksyari Dhofier dalam bukunya tradisi pesantren : "Lembaga-lembaga pesantren itulah yang paling menentukan watak keislaman dari kerajan-kerajan Islam dan yang memegang peranan penting bagi penyebaran Islam sampai kepelosok-pelosok. Dari lembaga lembaga pesantren itulah asal usul sejumlah manuskrip tentang pengajaran Islam di Asia Tenggara yang tersedia secara terbatas, yang dikumpulkan oleh pengembara-pengembara pertama dari perusahaan-perusahaan dagang Belanda dan Inggris sejak akhir abad ke-16. Untuk betulbetul memahami sejarah Islamisasi di daerah ini, kita harus mulai mempelajari lembagalembaga pesantren tersebut, karena lembaga inilah yang menjadi anak panah penyebaran Islam di wilayah ini."

Pertumbuhan dan perkembangan pesantren itu sangat pesat, jumlahnya bertambah banyak dan tersebar dipelosok-pelosok tanah air, hal ini disebabkan karena didukung oleh beberapa faktor sosio-kultural-keagamaan yang kondusif. Sehingga eksistensi pesantren ini semakin kuat berangkat dalam kehidupan dan kebudayaan masyarakat Indonesia.

Memasuki masa-masa represif pemerintah kolonial yang mulai sejak abad-17, pesantren mentrasformasikan sebagian peranannya dengan melibatkan diri dalam kancah perjuangan fisik dan politik. Telah banyak- kader-kader bangsa dan tokoh-tokoh perjuangan serta pahlawan-pahlawan kemerdekaan yang dilahirkan oleh pesantren. Banyak pesantren yang berperan sebagai basis kekuatan masa dan pahlawan rakyat melawan kaum penjajah Belanda. Misalnya, Pesantren Tebuireng di Jombang Jawa Timur asuhan K.H. Hasyim 
Asy'ari, telah dijadikan markas unit-unit pasukan Hisbullah melawan Belanda dalam perang Kemerdekaan ( 1945-1949).

Sesuai dengan latar belakang pesantren, dapat dilihat tujuan utama didirikannya suatu pesantren adalah untuk mendalami ilmu-ilmu agama (Tauhid, Fiqh, Usul Fiqh, Tafsir, Akhlak, Tasawuf, Bahasa Arab dan lain-lain). Diharapkan santri yang keluar dari pesantren telah memahami beraneka ragam mata pelajaran agama dengan kemampuan merujuk kepada kitab-kitab klasik.

Ada dua versi pendapat mengenai asal usul dan latar belakang berdirinya pesantren di Indonesia, yaitu:

Pertama, pendapat yang menyebutkan bahwa pesantren berakar pada tradisi Islam sendiri, yaitu tarekat. Pesantren mempunyai kaitan yang erat dengan tempat pendidikan yang khas bagi kaum sufi. Pendapat ini berdasarkan fakta bahwa penyiaran Islam di Inonesia pada awalnya lebih banyak dikenal dalam bentuk kegiatan tarekat. Hal ini ditandai oleh terbentuknya kelompok organisasi tarekat yang melaksanakan amalan-amalan zikir dan wirid tertentu. Pemimpin tarekat yang disebut Kiyai itu mewajibkan pengikutnya untuk melaksanakan suluk, selama 40 hari dalam satu tahun dengan cara tinggal bersama, sesama angota tarekat dalam sebuah masjid untuk melaksanakan ibadah-ibadah dibawah bimbingan Kiyai. Untuk keperluan suluk ini para Kiyai menyediakan ruangan khusus untuk penginapan dan tempat-tempat khusus yang terdapat di kiri kanan masjid. Disamping mengajarkan amalan-amalan tarekat, para pengikut itu juga diajarkan agama dalam berbagai cabang ilmu pengetahuaan agama Islam. Aktifitas yang dilakukan oleh pengikut-pengikut tarekat ini kemudian dinamakan pengajian. Dalam perkembangan selanjutnya lembaga pengajian ini tumbuh dan berkembang menjadi lembaga Pesantren.

Pendapat yang kedua adalah, pesantren yang kita kenal sekarang ini pada mulanya merupakan pengambil alihan dari sistem pesantren yang diadakan oleh orang-orang Hindu di Nusantara. Kesimpulan ini berdasarkan fakta bahwa jauh sebelum datangnya Islam ke Indonesia lembaga pesantren sudah ada di negri ini. Pendirian pesantren pada masa itu dimaksudkan sebagai tempat mengajarkan agama Hindu dan tempat membina kader. Anggapan lain mempercayai bahwa pesantren bukan berasal dari tradisi Islam alasannya adalah tidak ditemukannya lembaga pesantren di negara-negara Islam lainnya, sementara lembaga yang serupa dengan pesantern banyak ditemukan dalam masyarakat Hindu dan Budha, seperti di India, Myanmar dan Thailand. 
Pesantren di Indonesia baru diketahui keberadaan dan perkembangannya setelah abad ke 16. Pesantren-pesantren besar yang mengajarkan berbagai kitab Islam klasik dalam bidang fikih, teologi dan tasawuf. Pesantren ini kemudan menjadi pusat pusat penyiaran Islam seperti; Syamsu Huda di Jembrana (Bali) Tebu Ireng di Jombang, Al Kariyah di Banten, Tengku Haji Hasan di Aceh, Tanjung Singgayang di Medan, Nahdatul Watan di Lombok, Asadiyah di Wajo (Sulawesi) dan Syekh Muhamad Arsyad Al-Banjar di Matapawa (Kalimantan Selatan) dan banyak lainnya.

Dalam catatan sejarah, Pondok Pesantren dikenal di Indonesia sejak zaman Walisongo. Ketika itu Sunan Ampel mendirikan sebuah padepokan di Ampel Surabaya dan menjadikannya pusat pendidikan di Jawa. Para santri yang berasal dari pulau Jawa datang untuk menuntut ilmu agama. Bahkan di antara para santri ada yang berasal dari Gowa dan Talo, Sulawesi.

Pesantren Ampel merupakan cikal bakal berdirinya pesantren-pesantren di Tanah Air. Sebab para santri setelah menyelesaikan studinya merasa berkewajiban mengamalkan ilmunya di daerahnya masing-masing.

Sangat dianjurkan juga seorang santri calon kyai disamping menguasai ilmu-ilmu agama secara menyeluruh, secara kusus dia juga memiliki keahlian dalam bidang mata pelajaran tertentu, jadi semacam spesialisasi. Karena ada spesialisasi kyai-kyai tertentu, maka ini juga berpengaruh kepada spesifik pesantren yang diasuh oleh kyai tersebut. Misalnya Pesantren Al-Munawwir Krapyak Yogyakarta terkenal dengan spesialisasi al-Qur'an. Pesantren Lirboyo Kediri, spesialisasi nahwu-shorof, pesantren Tebuireng Jombang, terkenal sebagai spesialisasi ilmu Hadits, demikian juga pesantren-pesantren yang lainnya.

\section{HASIL}

\section{Ciri-ciri Pendidikan Pesantren}

Tuntutan pokok yang mesti dikuasai oleh santri adalah ilmu-ilmua gama Islam. Maka tidak boleh tidak, para santri mesti memahami ilmu-ilmu agama Islam itu dari sumber aslinya yaitu Al-Qur'an dan Al Hadits yang telah dijabarkan oleh ulama-ulama terdahulu dalam kitab-kitab klasik berbahasa Arab.

Untuk mengajarkan kitab-kitab klasik berbahasa Arab, Seorang kyai menempuh cara pembelajaran : wetonan, sorogan dan hafalan. Wetonan atau Bandongan (Jawa Barat) atau Halaqoh (Sumatera) adalah metode yang didalamnya terdapat seorang kyai yang membaca suatu kitab dalam waktu tertentu, sedangkan santrinya membawa kitab yang sama lalu santri 
mendengar dan menyimak bacaan kyai.Metode ini dapat dikatakan sebagai proses belajar mengaji secara kolektif. Sorogan adalah metode kuliah dengan cara santri menghadap guru seorang demi seorang dengan membawa kitab yang dipelajari.

Selain itu, metode hafalan juga menempati kedudukan yang penting di dunia pesantren. Pelajaran-pelajaran dengan materi-materi tertentu diwajibkan untuk dihafal. Seperti dalam pelajaran Al-Qur'an dan Hadist. Ada ayat-ayat tertentu dan hadist-hadist tertentu yang harus dihafalkan oleh santri. Demikian juga dalam hal pelajaran yang lain, seperti fiqh, bahasa Arab, tafsir, tasawuf, akhlak dan lain-lain. Hafalan-hafalan tersebut biasanya berbentuk nadham (sya'ir). Misalnya kaidah-kaidah Nahwu seperti Alfiah Ibnu Malik, merupakan bagian yang mesti dihafal oleh santri. Selain itu dilaksanakan juga metode musyawarah, yakni mendiskusikan mata pelajaran yang sudah dan akan dipelajari.

Bagi pesantren yang tergolong pesantren Khalafi (kekinian/modern),metode Sorogan dan wetonan bukanlah satu-satunya metode pengajaran.Mereka mempergunakan metodemetode pengajaran sebagaimana yang dipergunakan pada sekolah-sekolah umum. Karena itu pesantren tradisional tidak mengenal sistem kelas. Kemampuan siswa tidak dilihat dari tingkat kelasnya, tetapi dilihat dari kitab-kitab yang berhasil dikuasainya. Penanaman akhlaq sangat dipentingkan dalam dunia pesantren. Akhlaq sesama teman, kepada masyarakat sekitar, terlebih-lebih kepada kyai.

\section{Unsur-Unsur Pesantren}

Dalam keputusan loka karya intensifikasi pengembangan pondok pesantren yang diselenggarakan pada tanggal, 2 sampai 6 Mei 1978 di Jakarta, tentang pengertian pondok pesantren diberikan ta'rif sebagai berikut :

Pondok pesantren adalah lembaga pendidikan Islam yang minimal terdiri dari 3 unsur, yaitu :

a. Kyai/Syaikh/Ustadz yang mendidik serta mengajar.

b. Santri dengan asramanya

c. Masjid

Menurut Mukti Ali, dalam lembaga pendidikan Islam yang disebut pesantren, sekurang-kurangnya ada unsur kyai yang mengajar dan mendidik, santri yang belajar dari kyai, masjid sebagai tempat penyelenggaraan pendidikan, shalat berjamaah dan sebagainya, serta pondok atau asrama tempat tinggal para santri. Sementara itu Zamakhsari Dhofier menyebutkan lima elemen pesantren, yaitu : pondok, masjid, pengajian kitab-kitab klasik, santri dan kyai.Sesuai dengan hakekat dari suatu unsur misalnya kursi memiliki unsur dasar 
kayu, plastik dan logam,dan sesuai juga dengan apa yang ada di lapangan, menurut penulis, unsur atau elemen pesantren ada lima, dan secara berurutan dapat disebutkan yaitu : kyai, masjid, santri, pondok, dan pengajaran-pengajaran ilmu agama.

Selanjutnya dibawah ini akan dijelaskan unsur atau elemen pesantren sebagai berikut: a. Kyai

Kyai merupakan elemen yang paling esensial dari suatu pesantren. Dia adalah laksana jantung bagi kehidupan manusia. Kyai sering kali bahkan merupakan perintis, pendiri, pengelola, pengasuh, pemimpin atau bahkan pemilik tunggal sebuah pesantren.Kemasyhuran, perkembangan dan kelangsungan kehidupan suatu pesantren banyak tergantung pada keahlian dan kedalaman ilmu, kharismatik, wibawa dan keterampilan kyai yang bersangkutan dalam mengelola pesantrennya.Itulah sebabnya,banyak pesantren yang akhirnya bubar, lantaran ditinggal wafat oleh kyainya, sementara dia tidak memiliki keturunan atau murid yang mampu meneruskan perjuangannya. Itulah sebabnya kyai dianggap sebagai tokoh kunci yang menentukan corak kehidupan pesantren. Semua santri tunduk kepada kyai dalam arti berusaha menjalankan perintahnya dan menjahui larangannya, serta menjaga jangan sampai melakukan hal-hal yang sekiranya tidak direstui oleh kyai, sebaliknya mereka melakukan halhal yang sekiranya direstui kyai.

Seorang kyai seperti yang dikutip oleh Karel A. Steenbrink sangat ditentukan oleh faktorfaktor :

1) Pengetahuan $\quad$ 3) Keturunan

2) Keshalihan 4) Jumlah santrinya

Dalam menjalankan tugasnya ia dibantu oleh para pembantunya yaitu :

Kyai muda, santri senior atau ustadz, lurah pondok, serta para khadam yang mewakafkan dirinya kepada pesantren dalam rangka ngalap barokah kyai. Para pembantu Kyai memiliki tugas yang sama, yaitu berusaha menjelaskan jati diri kyai, baik visi, orientasi, maupun ajarannya.

Posisi kyai yang menjadi figur sentral di dunia pesantren tersebut, yang bagi santrinya merupakan sumber transformasi nilai-nilai ajaran Islam, sering kali dilihat sebagai orang yang senantiasa dapat memahami keagungan Tuhan dan rahasia alam. Sehingga dengan demikian mereka dianggap memiliki kedudukan yang tak terjangkau, terutama oleh kebanyakan orang awam. Anggapan santri kepada kyainya ini sebagai hasil interaksi sosial diantara keduanya, akan menimbulkan proses identifikasi yang pada akhirnya akan membentuk suatu kepribadian. Kyai adalah tokoh ideal bagi santri. 


\section{b. Masjid}

Secara harfiyah, masjid diartikan sebagai "tempat untuk bersujud" dalam arti terminologi, masjid diartikan sebagai tempat kusus untuk melakukan aktivitas ibadah dalam arti luas. Masjid merupakan elemen yang tak dapat dipisahkan dengan pesantren, sebab disitulah pada mulanya-sebelum pesantren mengenal sistem klasikal dilaksanakan proses belajar mengajar, komunikasi hubungan antara kyai dengan santri. Pada mulanya fungsi utama masjid adalah untuk melaksanakan shalat berjamaah, melakukan wirid dan do'a, i'tikaf, tadarus Al-Qur'an, sentral kebudayaan Islam, pusat organisasi kemasyarakatan, tempat pendidikan dan tempat pemukiman. Walaupun saat sekarang kebanyakan pesantren telah melaksanakan proses belajar mengajar di dalam kelas, tetapi bagi pesantren tertentu, masjid digunakan sebagai sentral untuk mendidik santri, terutama dalam praktik sembahyang 5 waktu, khutbah jum'ah dan pengajaran kitab-kitab klasik. Proses pengajaran di masjid biasanya menggunakan metode sorogan dan wetonan.

c. Santri

Istilah "santri" sebenarnya mempunyai dua konotasi atau pengertian.Pertama, adalah mereka yang taat menjalankan perintah agama Islam. Dalam pengertian ini, santri dibedakan secara kontrasdengan mereka yang disebut dengan kelompok "abangan", yaitu mereka yang lebih dipengaruhi oleh nilai-nilai budaya Jawa pra-Islam khususnya yang berasal dari mistisme Hindu dan Budha.Kedua, santri adalah mereka yang telah menuntut pendidikan di pesantren.

Pada pesantren yang tergolong masih tradisional, lamanya santri mukim di tempat itu bukan ditentukan oleh ukuran tahun atau kelas, tetapi diukur dari kitab yang dibaca. Kitabkitab itu ada yang bersifat dasar, menengah dan kitab-kitab besar. Semakin tinggi tingkatan kitab, semakin sulit memahami isinya. Karena itu para santri dituntut menguasai kitab- kitab dasar dan menengah, sebelum memasuki kitab-kitab besar atau tingkat tinggi.

\section{d. Pondok}

Istilah pondok boleh jadi diambil dari bahasa Arab Funduq yang berarti hotel, penginapan. Istilah pondok diartikan juga dengan asrama. Dengan demikian, pondok juga mengandung arti tempat tinggal. Dalam dunia pesantren, pondok merupakan unsur yang sangat penting karena berfungsi sebagai asrama dimana para santri tinggal bersama dan belajar dibawah bimbingan kyai, dan sekaligus sebagai pembeda dengan lembaga pendidikan yang berlangsung di masjid, surau atau langgar.

e. Pengajaran Ilmu-ilmu Agama 
Pengajaran ilmu-ilmu agama di pesantren pada umumnya dilaksanakan lewat pengajaran kitab-kitab klasik, disamping itu ada juga sebagian pesantren yang memakai kitab-kitab bahasa Arab tidak tergolong kitab-kitab klasik.

\section{1) Pengajaran Kitab-kitab Klasik}

Kemampuan membaca dan memberi sarah merupakan salah satu kriteria diterima atau tidaknya seseorang untuk menjadi ulama atau kyai pada zaman dahulu dan sekarang. Sedemikian tinggi kedudukan kitab-kitab Islam klasik, meskipun kebanyakan pesantren sekarang ini telah memasukkan pengajaran ilmu umum sebagai suatu bagian penting dalam pendidikan pesantren, namun pengajaran kitab-kitab klasik masih dimasukkan. Kitab-kitab Islam klasik yang diajarkan dipesantren digolongkan kedalam 10 kelompok, yaitu:

- Nahwu

- Shorof,

- Fiqh,

- Usul Fiqh,

- Hadist,
- Balaghah

- Tafsir,

- Tauhid,

- Tasawuf

- Tarikh

Kitab-kitab tersebut meliputi teks yang sangat pendek sampai teks yang terdiri dari berjilid-jilid yang tebal mengenai hadist, tafsir, fiqh, usul fiqh, fiqh dan tasawuf. Kesemuanya ini dapat pula digolongkan kedalam 3 kelompok, yaitu:

(1) kitab-kitab dasar,

(2) kitab-kitab tingkat menengah,

(3) Kitab-kitab besar.

2) Pengajaran Kitab-kitab Islam non Klasik

Bagi pesantren yang tergolong tradisional atau pesantren salafiyah, pengajian kitab-kitab Islam klasik mutlak dilaksanakan. Tidak demikian halnya pesantren yang tergolong modern. Bagi pesantren ini, pengajian kitab-kitab Islam klasik tidak mengambil bagian yang penting. Pengajian ilmu-ilmu agama diambil dari kitab-kitab yang berbahasa Arab yang disusun oleh ulama-ulama yang tergolong muta'akhirin (kekinian).

\section{Sejarah Perkembangan Pesantren}

Biasanya sebuah pesantren, yang sekaligus menjadi pusat gerakan dan praktekpraktek tarekat, mempunyai jaringan yang luas dengan pesantren-pesantren lainnya melalui jaringan ajaran dan gerakan-gerakan tarekat yang dipraktekkannya. Ajaran-ajaran dan gerakan-gerakan tarekat yang berkembang di pesantren inilah yang mempnyai daya tarik bagi 
masyarakat sekitarnya, yang dengan itu pesantren sekaligus memainkan peran aktifnya dalam proses islamisasi masyarakat sekelilingnya.

Terlepas dari dua versi di atas, yang jelas pesantren sebenarnya berembrio daripola pendidikan Islam pada masa lalu, ketika Rasulullah bemukim di Makkah, dia membuka pendidikan dan pengajaran di Dar Arqam. Di lembaga ini, para sahabat dididiktidak mengenal waktu, sehingga lahir pemimpin, ulama dan kader-kader Islam militan yang siap mengembangkan Islam ke daerah-daerah kekuasaan Persia Timur dan Romawi di Barat, hamya dalam waktu 35 tahun.

Pesantren berhasil menjadikan dirinya sebagai pusat gerakan pengembangan Islam, hal ini seperti yang diakui oleh Dr. Soebardi dan Prof. Johns, yang dikutip oleh Zamahksari Dhofier dalam bukunya tradisi pesantren : "Lembaga-lembaga pesantren itulah yang paling menentukan watak keislaman dari kerajan-kerajan Islam dan yang memegang peranan penting bagi penyebaran Islam sampai kepelosok-pelosok. Dari lembaga-lembaga pesantren itulah asal-usul sejumlah manuskrip tentang pengajaran Islam di Asia Tenggara yang tersedia secara terbatas, yang dikumpulkan oleh pengembara-pengembara pertama dari perusahaanperusahaan dagang Belanda dan Inggris sejak akhir abad ke-16. Untuk betul-betul memahami sejarah Islamisasi di daerah ini, kita harus mulai mempelajari lembaga- lembaga pesantren tersebut, karena lembaga inilah yang menjadi anak panah penyebaran Islam di wilayah ini."

Memasuki masa-masa represif pemerintah kolonial yang mulai sejak abad-17, pesantren mentrasformasikan sebagian peranannya dengan melibatkan diri dalam kancah perjuangan fisik dan politik. Telah banyak- kader-kader bangsa dan tokoh-tokoh perjuangan serta pahlawan-pahlawan kemerdekaan yang dilahirkan oleh pesantren. Banyak pesantren yang berperan sebagai basis kekuatan masa dan pahlawan rakyat melawan kaum penjajah Belanda. Misalnya, Pesantren Tebuireng di Jombang Jawa Timur asuhan K.H. Hasyim Asy'ari, telah dijadikan markas unit-unit pasukan Hisbullah melawan Belanda dalam perang Kemerdekaan (1945-1949).

Para kyai juga dikenal sebagai guru tarekat, telah mengambil bagian secara gigih, heroik dan patriotik dalam gerakan protes melawan Belanda. Semua ini membuktikan secara jelas bahwa para Kyai dan kaum penganut tarekat telah mengambil bagian secara aktif dalam kancah perjuangan politik dan fisik.

\section{PEMBAHASAN}

Islam masuk ke Indonesia sejak abad pertama hijriyah atau sekitar abad ke-7 atau 8 masehi. Daerah pertama yang didatangi Islam adalah pesisir pantai Sumatera, dan kerajaan 
Islam pertama berada di Aceh. Hasil seminar di Medan tahun 1963 tersebut diperkuat oleh hasil seminar masuk dan berkembangnya Islam di Aceh, yang diadakan pada tahun 1976.

Bila bertolak dari hasil seminar tersebut berarti pada sekitar abad ke-7 dan ke-8 Masehi telah tumbuh pusat-pusat pendidikan Islam di Indonesia tempat-tempat berlangsungnya pendidikan Islam pada tahap awal tersebut berpusat di masjid, surau, meunasah, rangkang dan dayah. Di pulau Jawa, lembaga pendidikan Islam bernama pesantren.

Biasanya sebuah pesantren, yang sekaligus menjadi pusat gerakan dan praktekpraktek tarekat, mempunyai jaringan yang luas dengan pesantren-pesantren lainnya melalui jaringan ajaran dan gerakan-gerakan tarekat yang dipraktekkannya. Ajaran-ajaran dan gerakan-gerakan tarekat yang berkembang di pesantren inilah yang mempunyai daya tarik bagi masyarakat sekitarnya, yang dengan itu pesantren sekaligus memainkan peran aktifnya dalam proses islamisasi masyarakat sekelilingnya.

Pesantren yang kita kenal sekarang ini pada mulanya merupakan pengambil alihan dari sistem pesantren yang diadakan oleh orang-orang Hindu di Nusantara. Sistem ini di negeri Hindu/Hindia sendiri dinamai sistem "Guru Kulo". Pada santri yang datang belajar khusus dari golongan bangsawan, tinggal dan menjadi kulo-warga dari guru yang berkasta tinggi, Brahmana.

Jumlah pesantren yang begitu banyak, dan memiliki aneka ragam bentuk, jenis dan spesifik, sudah barang tentu sangat sulit mempolakannya secara tajam dan jelas. Bukan suatu hal yang mustahil terjadi setelah pesantren-pesantren itu di klasifikasikan ke dalam beberapa pola, masih ada satu atau dua pesantren yang sulit untuk dikelompokkan ke pola mana ia masukkan.

Lembaga penelitian pendidikan dan penerangan ekonomi sosial padatahun 1973, juga berusaha mengelompokkan pesantren dengan mengambil lokasi di sekitar Bogor, Jawa Barat sebagai sampel penelitian. Dari pengelompokan itu dapat dilihat bahwa pesantren dapat dipolakan menjadi 5 pola, yaitu :

1) pola I; Masjid, rumah Kyai,

2) Pola II; Masjid, rumah kyai, pondok

3) Pola III; Masjid, rumah Kyai, pondok madrasah.

4) Pola IV; Masjid, rumah Kyai, pondok, madrasah, tempat ketrampilan.

5) Pola V; masjid, rumah Kyai, pondok, madrsah, tempat ketrampilan, universitas, gedung pertemuan, tempat olahraga, sekolah umum. 
Secara lebih terinci, Haidar Putra Daulay mengelompokkan pesantrendari segi isi atau materi yang diajarkan, atau dengan istilah lain dari segi kurikulumnya, standar pondok yang dijadikan tolok ukur didalam mengelompokkannya adalah materi pelajaran yang bersifat intra kurikuler dan metode penyampaian, yang diikuti pula dengan kepopuleran pola tersebut didunia pesantren yaitu :

Pola I, materi pelajaran yang dikemukakan di pesantren ini adalah mata pelajaran agama yang bersumber dari kitab-kitab klasik. Metode penyampaian adalah wetonan dan sorogan, tidak memakai sistem klasikal.Santri dinilai dan diukur berdasarkan kitab yang mereka baca. Mata pelajaranumum tidak diajarkan, tidak mementingkan ijasah sebagai alat untuk mencari kerja, yang paling dipentingkan adalah pendalaman ilmu-ilmu agama sematamata melalui kitab-kitab klasik.

Pola II, pola ini hampir sama dengan pola I di atas, hanya saja pola II proses belajar mengajar dilaksanakan secara klasikal dan non klasikal, juga dididik ketrampilan dan berorganisasi. Pada tingkat tertentu diberikan sedikit pegetahuan umum. Santri telah dibagi dalam jenjang pendidikan mulai dari tingkat Ibtidaiyah, Tsanawiyah, Aliyah dan metode yang digunakan adalah wetonan, sorogan, hafalan dan musyawarah.

Pola III, pada pola ini materi pelajaran telah dilengkapi dengan mata pelajaran umum, dan ditambah pula dengan memberikan aneka macam pendidikan lainnya, seperti ketrampilan, kepramukaan, olahraga, kesenian dan pendidikan keorganisasian dan sebagian telah melaksanakan program pengembangan masyarakat.

Pola IV, pola ini menitikberatkan pelajaran ketrampilan disamping pelajaran agama. Ketrampilan ditujukan untuk bekal kehidupan bagi seorang santri setelah tamat dari pesantren ini. Ketrampilan yang diajarkan adalah pertanian, pertukangan, dan peternakan.

Pola V, pada pola ini materi yang diajarkan di pesantren adalah sebagai berikut :

1. Pengajian kitab-kitab klasik.

2. Madrasah; di pesantren ini diadakan pendidikan model madrasah, selain mengajarkan mata pelajaran agama, juga mengajarkan mata pelajaran umum. Kurikulum madrasah pondok dapat dibagi menjadi dua bagian,pertama kurikulum yang dibuat oleh pondok sendiri dan kedua, kurikulum pemerintah dengan memodifikasi materi pelajaran agama.

3. Ketrampilan juga diajarkan dengan berbagai kegiatan ketrampilan.

4. Sekolah umum; dipesantren ini dilengkapi dengan sekolah umum, materi pelajaran umum pada sekolah umum yang ada di pesantren seluruhnya berpedoman pada kurikulum Departemen Pendidikan dan Kebudayaan. Sedangkan materi pelajaran agama disusun 
oleh pondok sendiri. Di luar kurikulum pendidikan agama yang diajarkan di sekolah, pada waktu-waktu yang sudah terjadwal santri menerima pendidikan agama lewat membaca kitab-kitab klasik.

5. Perguruan tinggi, pada beberapa pesantren yang tergolong pesantren besartelah membuka universitas atau perguruan tinggi.

\section{KESIMPULAN}

Pesantren merupakan lembaga pendidikan Islam Indonesia yang bertujuan untuk mendalami ilmu agama Islam, dan mengamalkannya sebagai pedoman hidup keseharian atau tafaqquh fi al din dengan menekankan pentingnya moral hidup bermasyarakat. Dalam pesantren, menuntut ilmu lebih mementingkan unsur keikhlasan, bukan mencari pangkat, kedudukan maupun harta.

Terdapat ciri khas dari Pondok pesantren yang merupakan lembaga pendidikan Islam yang minimal terdiri dari 3 unsur, yaitu : Kyai / Syaikh / Ustadz yang mendidik serta mengajar, santri dengan asramanya dan masjid. Ketiga unsur ini tidak bisa dipisahkan apalagi tidak ada salah satunya. Jika hilang satu unsur dari ketiganya, maka batal makna dari lembaga pendidikan tersebut dari nama Pesantren.

Pola pendidikan dalam pesantren adalah pertama materi pelajaran bersumber dari kitab-kitab klasik, kedua proses belajar mengajar dilaksanakan secara klasikal dan non klasikal, dan ketiga adalah materi pelajaran telah dilengkapi dengan mata pelajaran umum, dan ditambah pula dengan memberikan aneka macam pendidikan lainnya, seperti ketrampilan, kesenian, kepramukaan, keorganisasian, olahraga.

\section{DAFTARPUSTAKA}

A. Hasyimy. 1969. Sejarah Masuk dan Berkembangnya Islam Di Indonesia. Bandung Al-Ma'arif.

Abdullah, M. Amin. 1996. Studi Agama : Normativitas atau Historitas? Yogyakarta : Pustaka Pelajar.

Abdurrahman, Muslim. 1997. Islam Transformatif. Jakarta: Pustaka Firdaus.

Addullah, Taufik. 1987. Islam dan Masyarakat: Panutan Sejarah Indonesia. Jakarta: LP3ES. Ali, Mohamad Daud. 1995. Lembaga-lembaga Islam di Indonesia. Jakarta: Raja Grafindo Persada.

Ali, Mukti. 1986. "Pondok Pesantren Dalam Sistem Pendidikan Nasional". dalam Pembangunan Pendidikan dalam Pandangan Islam. Surabaya: IAIN Sunan Ampel. 
Al-Shaibani, Omar M. al-Taumi. 1979. Filsafat Pendidikan Islam. terj. Hasan Langgulung. Jakarta: Bulan Bintang.

Ansari, Hanafi. 1983. Pengantar Ilmu Pendidikan. Surabaya: Usaha Nasional.

Anwar Qomar. 1998. "Manajemen Pendidikan Islam”, Solusi Islam Atas Problematika Umat ed. Adi Sasono dkk. Jakarta: Gema Insani.

Azra, Azyumardi. 1997. "Pesantren Kontinuitas dan Perubahan", dalam Bilik-Bilik Pesantren: Sebuah Potret Perjalan, ed. Nurcholis Madjid, Jakarta: Paramadina.

Bahtiar, Wardi. 1990. Laporan Penelitian Perkembangan Pesantren di Jawa Barat. Bandung: Balai Penelitian IAIN Sunan Gunung Jati.

Binti Fatimah. 1987. "The Malaysian Educatioan System and Islamic Educational Ideal". dalam Muslim Educational Quarterly 2 Cambridge. United Kingdom : Islamic Academi.

Faisal Ismail. 1997. Paradigma Kebudayaan Islam: studi Kritis dan Refleksi Historis. Yogyakarta: Titihan Illahi Press.

Husni Rahim. 2001. Arah Baru Pendidikan Islam di Indonesia. Jakarta: PT Logos Wacana Ilmu.

Muhammad Jamhuri, Lc., MA. 1990. Sejarah dan Perkembangan Pendidikan Islam di Indonesia.Tangerang: Sekolah Tinggi Agama Islam Asy-Syukriyyah.

Solichin Salam. 1963. K.H. Hasyim Asy'ari: Ulama Besar Indonesia. Jakarta: Jaya Murni. 1963.

Standarisasi Pengajaran Agama di Pondok Pesantren. 1984/1985. Jakarta: Departemen Agama RI.

Suryadi Siregar DEA. 1996. Pondok Pesantren Sebagai Model Pendidikan Tinggi. Bandung: Kampus STMIK Bandung.

Zamakhsyari Dhofier. 1882. Tradisi Pesantren Studi Tentang Pandangan Hidup Kyai. Jakarta: LP3ES. 